\title{
ON THE LIFE AND WORK OF JOHANNES DE VESALIA-GREAT-GRANDFATHER OF ANDREAS VESALIUS
}

by

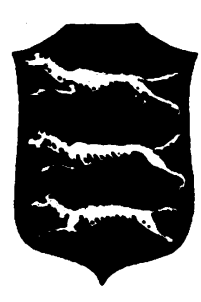

\section{LUIGI BELLONI}

THE striking coat of arms of the three weasels-in Flemish weselstands out at the head of the magnificent frontispiece of De humani corporis fabrica (Basle, 1543), the work which procured for Andreas Vesalius (1514-64) the title of 'Father of Modern Anatomy'. The great anatomist's family, called Wijtinck ('Witingorum familia'), did in fact originate from the 'antiquissima et celeberrima Cliviae Wesalia', the town of Wesel in the Rhenish area of Cleves. This origin is affirmed-together with other, and not always reliable, genealogical records-by Andreas Vesalius himself in his letter of 1546 on the subject: 'propinandi radicis Chynae decocti, quo nuper invictissimus Carolus $\mathrm{V}$ imperator usus est'.

Ten years later, on 21 April I556, the Emperor Charles V-soon to abdicate -raised his Court Physician to the dignity of Count Palatine 'cum nobilitatione et melioratione armorum'. The pertinent charter, recently published by Charles D. O'Malley, ${ }^{2}$ contains other genealogical particulars, not lacking in embellishment. We learn from this charter that the above-mentioned coat of arms-'arma nigri seu sabellini coloris' in which 'tres albae seu argenteae mustellae' set offwas granted by the Emperor Frederick III to Andreas' great-grandfather, by name John, Professor of Medicine at Louvain, who was the first of the family to assume the surname of Wesalia, which he subsequently transmitted to his descendants: 'proavo tuo Joanni, qui cum Lovanij primis disciplinis operam dabat et medicinae artem docuit, de Wesalia ut illic moris est, a natali solo studiosis cognomine imponendo, ita fuit appellatus, ut eius nomen vobis posteris suis extitit occasio'.

Historians of our century have already, on more than one occasion, shown their interest in the said Johannes de Vesalia, to whom their attention was drawn by Alphonse Wauters 3 in 1897 .

From the year 1429, Johannes de Vesalia taught at Louvain University, founded in 1426; and before reaching that office he had already obtained his degree in medicine elsewhere. We find him mentioned for the last time in the annals of Louvain University as far back as 1447. Then follows a wide gap in the record of his life; and in $147 \mathrm{I}$ he appears as physician to the city of Brussels, although we do not know in what year he was entrusted with that office. He died before 28 May 1476 , on which date his estate was divided up by his heirs.

The compiler of the 1556 charter previously mentioned clearly ascribes to him great and imperishable merits as a writer: '. . . insuper etiam praefati 


\section{Luigi Belloni}

proavi tui Joannis Vesalij-cuius et in astronomia et in medicina in communem studiosorum utilitatem edita monumenta adhuc passim in multorum manibus versantur-erga rem publicam literariam praeclara merita'; but it was not until 1956 that his first pamphlet was published: a 'judicium astrologicum', which, in the opinion of A. Abel and Mina Martens, ${ }^{4}$ his editors, goes back to 1472 and was written for Charles the Bold, Duke of Burgundy.

His literary activity 'in medicina', however, remained to be documented; and the purpose of this paper is to contribute towards this end. It aims at attributing the authorship of a treatise on the plague-dedicated to Francesco Sforza, Duke of Milan (1450-66), by a 'Johannes de Vesalia nuper' sui Papiensis gignasii doctor medicine' - to the great-grandfather of Andreas Vesalius: and I should like to point out here that a Johannes de Vesalia is shown to have obtained his degree in medicine at Pavia on 23 January $1427 .^{\circ}$

For many years I have been studying this treatise: and have already included it in summarized form in the Storia di Milano, ${ }^{7}$ leaving the identification of the author to a transcription, even though only provisional,* of the text. This work, concluded for the quater-centenary of Vesalius ( $1564 / 1964)$, has proved fruitful, since the result appears to confirm the starting hypothesis. The conclusions arrived at up to the present are given in this paper, whilst a more profound analysis of the treatise 8 will be made on the occasion of the "Academica commemoratio gentium actione ad quartum centenarium annum Andreae Vesalii defuncti' which is to be held in Brussels this October.

The treatise on the plague by Johannes de Vesalia is at present known to me in two contemporary (mid-fifteenth century) manuscripts, of which I give here only a brief outline:

(I) The miscellany MS. Vat. Reg. lat. 1450, in which the treatise fills the paper folios $\mathrm{I}-24\left(2 \mathrm{I} \times 28.5 \mathrm{~cm}\right.$.). A marginal note at foot on $\mathrm{f}$. $\mathrm{I}^{\mathrm{r}}$ indicates this MS. as 'Volumen CXLV. non Petavianum': and this exclusion is confirmed by another marginal note at top right: 'Numero 1450. non Pet. 1656'. The inscription 'Bourdelot' indicates that the MS. reached the collection of Queen Christina of Sweden (1626-89) from the library of her physician Pierre MichonBourdelot (16ro-85).$^{10}$ The text is unfortunately mutilated and ends at f. $24^{v}$ with the words 'sapores ex succis' corresponding to the eleventh line of $f_{.} 3^{1^{r}}$ of the Rosminian MS. This mutilation, which involves the loss of approximately one-third of the text, is all the more serious inasmuch as the Reg. MS. (written beyond the Alps) is considerably more reliable than the other.

(2) The MS. of the Rosminian Library (Stresa) ${ }^{11}$ is made up of $49 \mathrm{ff}$. in parchment, n.n., the dimensions being $17 \times 25 \mathrm{~cm}$. Folio $\mathrm{I}^{\mathrm{r}}$ is ornamented with miniatures, among which is a shield without coat of arms: in the subsequent pages, too, many initials are illuminated. The parchment of the rear cover bears at the foot the signature of the miniature-painter and book-binder (EGO IACOBUS DE SANCTO PETRO HOC OPUS AMINIAVI ET LIGAVI PAPIE): a beadle of Pavia known to have bound other manuscripts of the Library of Visconti and Sforza. ${ }^{12}$ The parchment of the front cover, on the other hand,

* In preparation for publication. 


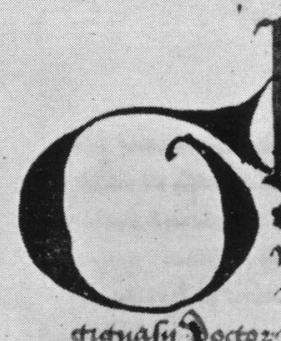

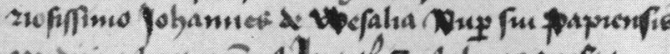

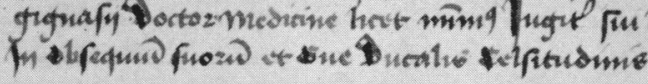

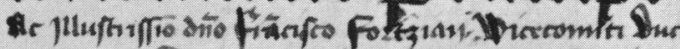

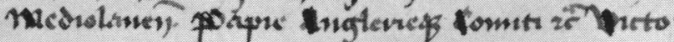

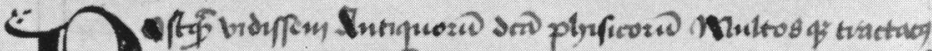

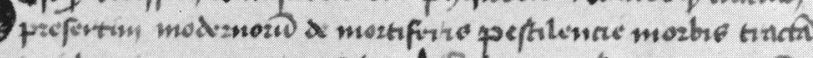

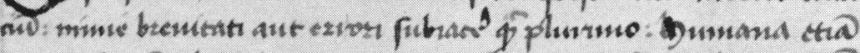

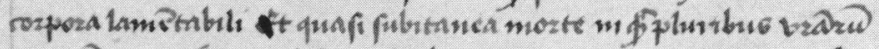

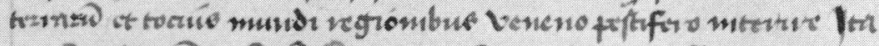
ut trim mo

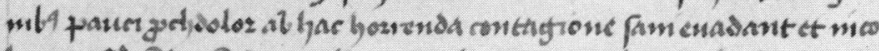

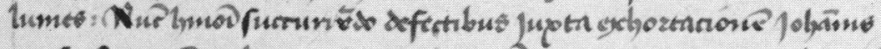

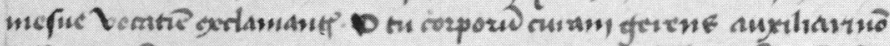

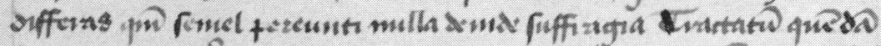

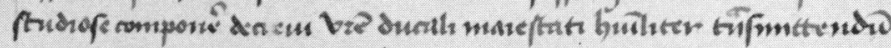

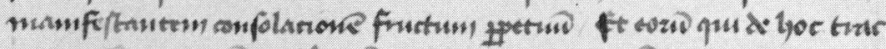

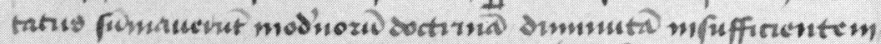

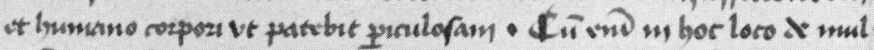

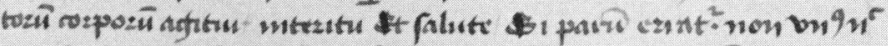

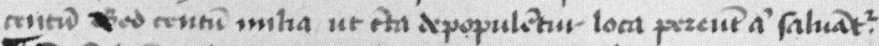

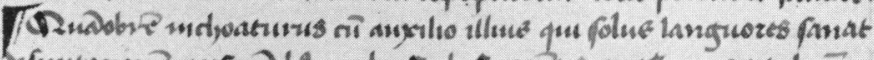

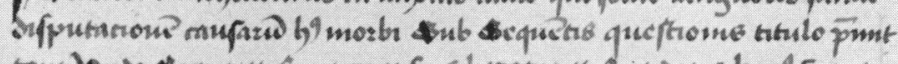

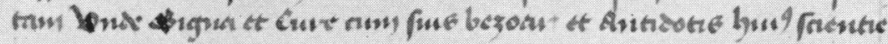

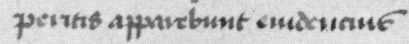

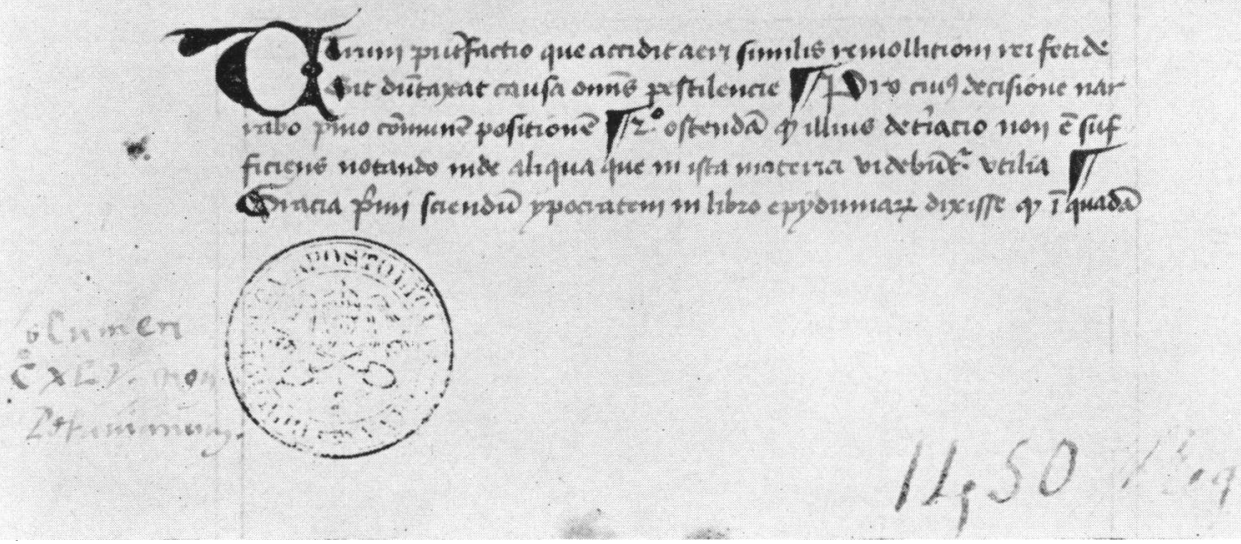

Figure I. The treatise on the plague by Johannes de Vesalia with dedication to Francesco Sforza, Duke of Milan. Folio $\mathbf{I}^{\mathbf{r}}$ of MS. Vat. Reg. lat. I450, paper, $\mathrm{XV}$ century, $2 \mathrm{I} \times 28.5 \mathrm{~cm}$. 


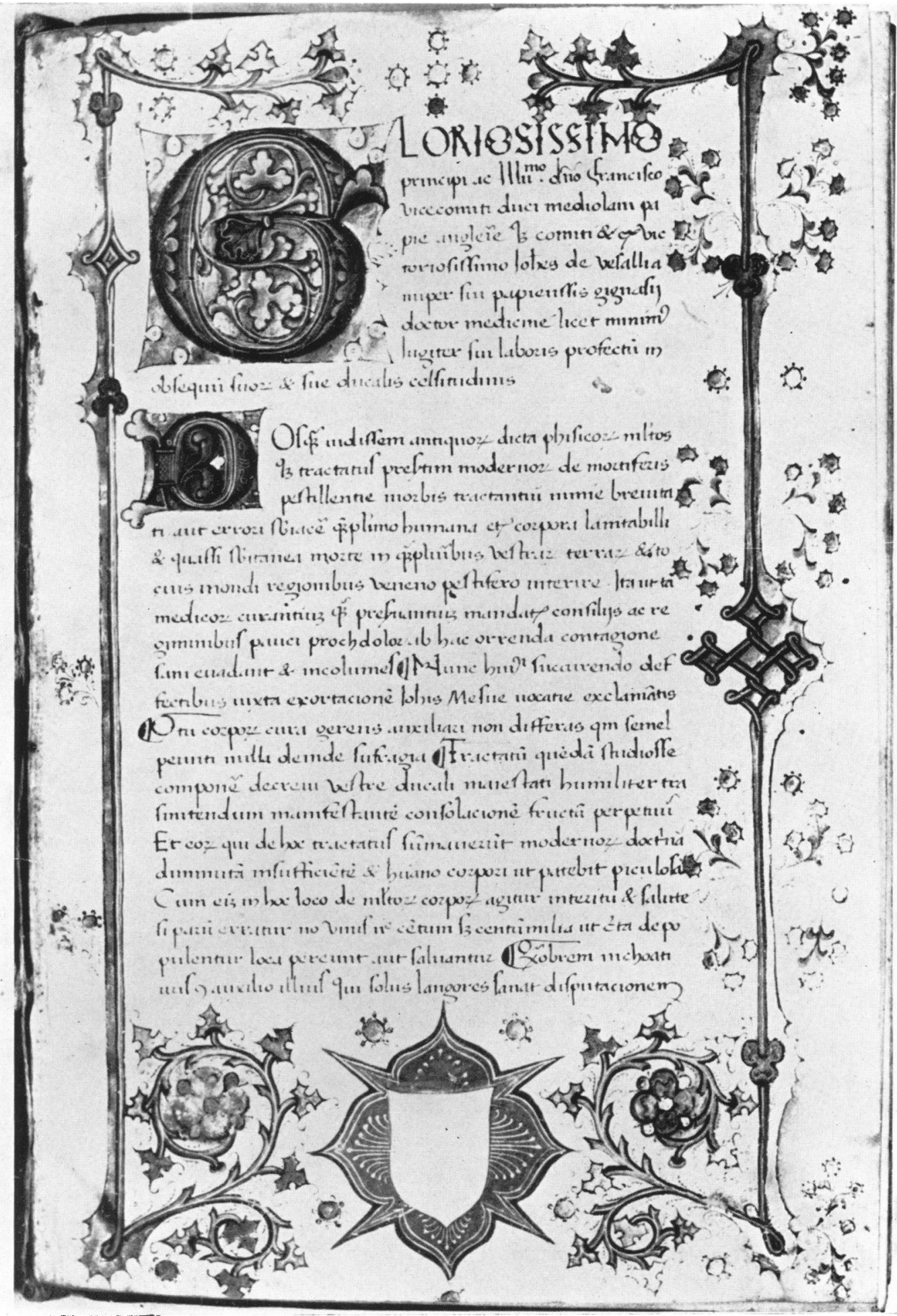

Figure 2. The treatise on the plague by Johannes de Vesalia with dedication to Francesco Sforza, Duke of Milan. Folio $I^{r}$ of the Rosminian MS., parchment, $\mathrm{XV}$ century, $\mathrm{I} 7 \times 25 \mathrm{~cm}$. 


\section{On the Life and Work of Johannes de Vesalia-Great-grandfather of Andreas Vesalius}

bears the inscribed ex-libris 'Sac. Dominici Ceroni', who gave it to Professor Giuseppe Paggi, of the Rosminian Congregation, who, in his turn, bequeathed it to the Rosmini College of Domodossola, whence it was transferred a few years ago to Stresa.

The text of the Rosminian MS. is unfortunately lacunose and corrupt, and this fact does not agree with the hypothesis that it may be the dedicated copy. Nevertheless, in the brief summary notes on the subdivision of the treatise which follow, reference to the collation of the Rosminian MS. will prove more convenient because, as it has not suffered the serious mutilation found in the Reg. MS., it enables an idea to be given of the relative proportions of the various parts into which the text is subdivided, as follows:

(A) On f. I a preface, which is worthy of being reported in full since in it the author explains his aims in writing the work:

Postquam vidissem antiquorum dicta phisicorum, multosque tractatus presertim modernorum de mortiferis pestilencie morbis tractancium, nimie brevitati aut errori subiacere quamplurimo, humana etiam corpora lamentabili et quasi subitanea morte in quampluribus vestrarum terrarum et tocius mundi regionibus veneno pestifero interire, ita ut tam medicorum curantium quam preservancium mandatis consiliis ac regiminibus pauci proch dolor ab hac horrenda contagione sani evadant et incolumes, nunc huiusmodi succurrendo defectibus iuxta exhortacionem Iohannis Mesue vocative exclamantis ' $O$ tu corporum curam gerens, auxiliari non differas quoniam semel pereunti nulla deinde suffragia', tractatum quendam studiose componere decrevi vestre ducali maiestati humiliter transmittendum, manifestantem consolacionem fructum perpetuum et eorum qui de hoc tractatus summaverunt modernorum doctrinam diminutam insufficientem et humano corpori, ut patebit, periculosam. Cum enim in hoc loco de multorum corporum agitur interitu et salute, si parum erratur, non unus nec centum sed centum milia, ut certa depopulentur loca, pereunt aut salvantur. Quamobrem inchoaturus cum auxilio illius qui solus languores sanat, disputacionem causarum huius morbi sub sequentis questionis titulo premittam, unde signa et cure cum suis bezoar et antidotis huius scientie peritis apparebunt evidencius.

(B) On ff. $I^{\nabla}-I^{\nabla}\left(=\right.$ Reg. $\left.I^{r}-8 v\right)$, a long and erudite nosological and etiopathogenetic dissertation, ending with an exhaustive statement of local lesions, especially cutaneous.

On f. $4^{\mathrm{v}}\left(=\right.$ Reg. $\left.3^{\mathrm{v}}\right)$ the author puts forward an observation taken direct from his own experience:

Etiam testor me vidisse in pestilencia anni $28 .^{\text {vi }}$ opidi Traiectensium superiorum et $39 .{ }^{\text {ni }}$ apud Lovanienses et nunc $54^{\text {ti }}$ Bruxellensis post exhibitionem clisteriorum in $3 .^{\mathrm{a}}$ vel in $4^{\text {ta }}$ assellatione rem exire nigerrimam in principio morbi quasi ebulientem ac motam assando ac si vita participaret cum magna infirmi alleviatione.

The city of Brussels is again mentioned on $\mathrm{f} .5^{\nabla}\left(=\right.$ Reg. $\left.4^{\nabla}\right)$ where the distinction is made between epidemic, endemic and pestilence:

Undimia autem dicitur morbus pluribus communis consuetus et cognitus in una civitate vel loco quasi ab intus eveniens, et est magis propter aquam illius loci, vel ventum ibidem regnantem, vel propter fundum, sicut apparet in quibusdam civitatibus nefresis, ut Bruxellensi et eius vicinio, in quibusdam botium, ut in montibus. . . .

(c) On ff. $11^{v}-16^{r}\left(=\right.$ Reg. $\left.8^{v}-1 I^{v}\right)$ the description of the 'signa pronostica' and 'signa demonstrativa'. The starting-point is the constellations: and the 


\section{Luigi Belloni}

author handles the subject with the mastery already observed in the judicium astrologicum' mentioned above. The description of the meteoric-climatic phenomena derived from superior influences, and the indications which may be deduced from the behaviour of animals and vegetables are accurately drawn. A consequence of such influences is famine, such as for example the 'ultima caristia' mentioned at f. $13^{v}\left(=\right.$ Reg. $\left.{ }^{v}{ }^{r}\right)$. This part of the treatise ends with a description of the clinical symptomatology, and especially of signs which are useful in differentiating genuine plague from other febrile diseases and in formulating the prognosis.

(D) On ff. $16^{\mathrm{r}}-28^{\mathrm{r}}\left(=\right.$ Reg. $\left.11^{\mathrm{v}}-23^{\mathrm{r}}\right)$ the author puts forward a preliminary to the actual 'regimen preservativum et curativum' 28 'considerationes' with the help of which 'regimen tale fundamentalius et securius registratur'.

The 'colera vitellina' is the subject of the first consideration, in which we read on $f .16^{v}\left(=\right.$ Reg. $\left.12^{r}\right)$ :

Consideratis ergo a nobis epidimiis fluxuum et pestium in latissimis locis, ut annis ubi supra, presertim nunc annis 52. 53. et 54. currentibus circa confinia Flandrie et Brabancie, apparet in neutralitate decidencie et in ipsamet egritudine actuali quod colera ista sic vocata calore adustivo aut putredinali contabescente humido plurimum generatur a sanguine et chilo.

The plague of 1454 in Brussels, already mentioned on f. $4^{v}\left(=\right.$ Reg. $\left.3^{v}\right)$, reappears in this extract, as it will recur further on at the end of the same 'consideratio' (f. $18^{v}=$ Reg. $13^{v}$ ): 'Similiter vidimus sepe eam multum viscosam unctuosam vel non unctuosam cum igneo vitellino colore etiam rubeo obscuro in currentibus epidimiis.'

The eleventh 'consideratio', which deals with meteorology, refers explicitly to the estates belonging to the duke to whom the treatise is dedicated (f. $22^{\mathrm{r}}$ $=$ Reg. $16^{r}$ ): '. . . situs et qualitas montium, sicut venti omnes in terris Lombardie infrigidantes preter austrum, et mare aque nostre salse, in quo est maior fluxus et refluxus. ....'

The twelfth 'consideratio' stops after eleven lines in the Rosminian MS. (f. $22^{v}$ ), whereas it continues in the Reg. MS. (ff. $16^{v}-17$ ), testifying once more to the author's activities in the Brussels plague: 'Similiter post lenitionem traximus Bruxellis in uxore cuiusdam nobilis, apostemate in sinistro colli existente magno, cum tensione colli et vomitu virtute fortiori, per flobotomiam sinistri pedis, apostema aqua et succo scabiose fortissime alterando, unde evanuit....'

Following the twenty-eight 'considerationes', which are numbered, there is another on the pestilential foetor, very long and unnumbered, preserved in full in the Reg. MS. (ff. 22-23 ), whilst it is only mentioned in the Rosminian MS. (f. $28^{\mathrm{r}}$ ).

(E) On the ff. $28^{\mathrm{r}}-49^{\mathrm{r}}$ the part that may be defined as the essence of the work, that is to say the 'regimen corporis tempore pestifero, quod divisum est in artem preservativam et curativam: et unumquodque eorum bipartitum est in regimen non naturalium rerum et medicinalium'. There then follow:

(a) On ff. $28^{\mathrm{v}}-3^{\mathrm{v}}$ (=Reg. $23^{\mathrm{r}}-24^{\mathrm{v}}$ mutil.) the prophylactic dietetic 'regimen': and here the author, even though dedicating the work to an Italian prince, dwells upon a drink which is widely used in Flanders: '. . . aut cervisia utantur 
aut hupa clara bone residencie presertim pure de bono blado et aqua sana. Et valent cervisie orientales et etiam maritine postquam tracte per diem resederint et ambe fuerint satis antique vitando malvasiam muscadellam et mellita' (f. $30^{v}$ ). In the Reg. MS. this extract is found on f. $24^{v}$, not long before the mutilation of the text.

(b) On ff. $32^{\mathrm{v}}-3^{\mathrm{r}}$ the prophylactic medicinal 'regimen'.

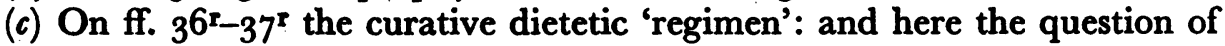
beer is again considered:

Aut pro pauperibus aqua simplex ellecta aut cocta infrigidata cum modico boni aceti aut aliqua minima cervisia terre nostre. Item ordeatum cum amigdalis anetatum acetosatum poma aromatica stiptica cocta et infrigidata. Aut brodnitum de pane et aqua cum zucharo et verguto aut vino bruscho. Et in nostra regione aliquid de cervisijs parvis addendo et gruellum bibendo (f. $3^{6 v}$ ).

(d) On $\mathrm{ff} .37^{\mathrm{r}}-43^{\mathrm{v}}$ the curative medicinal 'regimen', which includes the 'curatio morbi' (ff. $37^{\mathrm{r}}-39^{\mathrm{v}}$ ) and the 'curatio apostematis' (ff. $39^{\mathrm{v}}-43^{\mathrm{v}}$ ). With regard to the last-mentioned, the author calls to mind a poultice used by some citizens of Maastricht:

Verumtamen in glandulla proprie et etiam in petracha convenit emplastrum quorundam Traiactenssium superiorum de extremitatibus sambuci seminibus sinapis cum modico tiriace: facit enim (ad) dolorem et atrahit cito et infra horam. Proprie autem valet quando iam glandulla manet in corpore et reddit retro post remotionem medicine istius. Quidam vero fracie(!) superiorum fecerunt decoctionem tiriace ellecte in cepe sub prunis addendo aliquid aceti ... (f. $\left.42^{\mathrm{r}}\right)$.

Furthermore, in the chapter on the treatment of the apostema an observation made by the author 'in quodam duce Alamanie' (f. $\mathbf{4 2}^{\mathrm{v}}$ ) is mentioned.

(e) On ff. $44^{\mathrm{r}}-49^{\mathrm{r}}$ four 'dubia' are formulated and resolved, at the end of which the treatise concludes at f. $49^{\mathrm{r}}$ with the following explicit: 'Quam ob rem evigilletur peritorum animus ampliora volentium indagare, quorum speculationes splendores et actiones sinceras ille supernus opifex dirigere et irradiare dignetur, qui facit surdos audire, cecos videre et mutos loqui, regnans in secula seculorum. Amen.'

The data which emerge, either directly or indirectly, from the treatise on the plague-and are shown by the words in italics-are easy to insert into the biographical data already in our possession concerning Johannes de Vesalia, as will be seen from the following chronological table:

1427-23 January-licentia et doctoratus in medicina at Pavia

1428 - the plague of Maastricht

I429-commencement of teaching at Louvain University

1439 - the plague of Louvain

1447 -last record at Louvain University

1454-the plague of Brussels

(proposed date of the drafting of the treatise on the plague)

1471 - first record in Brussels as physician of that city

1476-28 May-division of estate among heirs 


\section{Luigi Belloni}

\section{REFERENCES}

1. Andreae Vesalii Bruxellensis, medici Caesarei, Epistola, rationem modumque propinandi radicis Chynae decocti, quo nuper invictissimus Carolus V. Imperator usus est, pertractans: et praeter alia quaedam, epistolae cuiusdam ad Iacobum Sylvium sententiam recensens, veritatis ac potissimum humanae fabricae studiosis perutilem, quum qui hactenus in illa nimium Galeno creditum sit, facile commonstret, Basileae, 1546, pp. 196-7.

2. O'MAlley, G. D., Andreas Vesalius, Count Palatine: further information on Vesalius and his ancestors, J. Hist. Med., 1954, 9, 196-223.

3. Wa t t r R, A., Quelques mots sur André Vésale, ses ascendants, sa famille et sa demeure à Bruxelles nommée la maison de Vésale, Mémoires couronnés et autres mémoires publiés par l'Académie Royale des sciences, des lettres et des beaux-arts de Belgique, 1897, 55, 1-75.

I recall among the more recent works:

Spelkens, E., Généalogie de la famille d'André Vésale (Wijtinck, dictus van Wesele), L'intermédiaire des généalogistes, 1961, 16, 64-75, 197-8. F R AIN E, P. J. DE, Het artsengeslacht van Wesele (Vesalius) en het 'Zoet Water' bij Leuven, Eigen Schoon en de Brabander, 1962, Nos. 8-9-10, pp. 285-95.

4. Aber, A., and Martens, M., Le rôle de Jean de Vésale, médecin de la ville de Bruxelles, dans la propagande de Charles le Téméraire, Cahiers Bruxellois, I956, r, 4I-86.

5. On the use of 'nuper' to describe a considerable lapse of time, see Cicero, De divinatione, I, 39 ('Neque ante philosophiam patefactam, quae nuper inventa est'); De natura Deorum, II, 50 ('Ea quae nuper, id est paucis ante saeculis reperta sunt').

6. Codice diplomatico dell'Universitd di Pavia, II/1, Pavia 1913, p. 328, doc. 478.

7. Belloni, L., La medicina a Milano fino al Seicento, Storia di Milano della Fondazione Treccani degli Alfieri, 1958, I r, 6rg, with reproduction of $f$. $\mathrm{I}^{\mathrm{r}}$ of the MS. Rosmin.

8. Also in relation to other treatises of the same period, such as De praeservatione a peste et eius cura (1444/9 ca.) by Michele Savonarola (1385 ca.-1464). Cp. SAvonAROLA, M., I trattati in volgare della peste e dell'acqua ardente editi da Luigi Belloni, Milano, 1953.

9. Meye R, K. A. De, Paul en Alexandre Petau en de geschiedenis van hun handschriften (voornamelijk op grond van de Petau-handschriften in de Universiteitsbibliotheek te Leiden), Leiden, 1947.

1о. Омолт, H., Catalogue des manuscrits de Jean et Pierre Bourdelot médecins Parisiens, Revue des Bibliothèques, I891, r, 81-103 (No. 247, p. 97).

I1. Romano, G., Un codice pavese a Domodossola, Boll. d. Soc. Pavese di storia patria, 1903, 3, 471-2. PAScal, G., Di un codice medicinale del sec. XV, Athenaeum (Pavia), 1913, I, I12-14.

12. Pellegrin, E., La bibliotheque des Visconti et des Sforza ducs de Milan, au XV siecle, Paris, 1955, pp. 399-400. 